\title{
Association of nymphs and adults of Ephemeroptera (Insecta) using the amplified fragment length polymorphism (AFLP) technique
}

\author{
Lucimar G. Dias $^{1 *}$, Tito Bacca ${ }^{2}$, Lucio Navarro ${ }^{3}$, Flor E. Acevedo ${ }^{3}$, Pablo M. Benavides ${ }^{3}$ \\ and Paulo Sérgio Fiuza Ferreira ${ }^{4}$ \\ ${ }^{1}$ Departamento de Ciencias Biológicas, Facultad de Ciencias Exactas y Naturales, Universidad de Caldas, Colombia \\ ${ }^{2}$ Facultad de Ciencias Agrícolas, Universidad de Nariño, Torobajo, Pasto, Nariño, Colombia \\ 3 Disciplina de Entomología, Cenicafé, Chinchiná, Caldas, Colombia \\ ${ }^{4}$ Museu de Entomologia, Departamento de Biologia Animal, Universidade Federal de Viçosa, Minas Gerais, Brazil
}

Received 29 August 2010; Accepted 22 February 2011

\begin{abstract}
Many species of Ephemeroptera have been described based on either nymphs or adults. Only $10 \%$ of Ephemeroptera species in South America are known in both life stages. The current research was carried out in order to molecularly associate nymphs and adults of Ephemeroptera, using the amplified fragment length polymorphism (AFLP) technique. We obtained molecular fingerprints by the AFLP of five species: Leptohyphes albipennis, Leptohyphes coconuco, Leptohyphes ecuador, Baetodes levis and Prebaetodes sitesi. The association between nymphs and adults of L. albipennis and L. coconuco by this analysis confirmed the effectiveness of the technique. The molecular fingerprints of B. levis and P. sitesi were generated with the hope that future collections of unknown adults would match the fingerprint and solve an identification problem. We describe here for the first time the adult of L. ecuador by matching an adult trapped in the field with the DNA fingerprint of nymphs obtained by means of AFLP.
\end{abstract}

Key words: Ephemeroptera / nymphs / adults / association / DNA / AFLP / fingerprint

\section{Introduction}

The order Ephemeroptera is a diverse and important component of freshwater ecosystems and has been considered an excellent indicator of quality of water (Resh and Jackson, 1993; Domínguez et al., 2006; Menetrey et al., 2008). The nymphs play a significant role in nutrient recycling; they are involved in processing organic matter in water streams (Merritt and Cummins, 1996; Grant, 2001; Domínguez et al., 2006). The nymphal life span in mayflies varies from 3-4 weeks to about 2.5 years. In contrast, the adults do not feed and rely on reserves built up during their nymphal life and live from a few hours to a few days depending on the species (Brittain, 1982).

Ephemeroptera is a small group of winged insects, represented by over 3000 described species in 42 families and more than 400 genera. The highest generic diversity occurs in the Neotropics, with correspondingly high species diversity (Barber-James et al., 2008). In South America, approximately 15 families and 450 species

\footnotetext{
*Corresponding author: lucimar.dias@gmail.com
}

distributed in 100 genera are reported (Domínguez et al., 2006). Despite the effort to know Ephemeroptera in this region, the fauna of many areas remains uncollected, and many species and stages of life remain undescribed (Domínguez et al., 2006).

In taxonomic descriptions of Ephemeroptera species, the lack of association between nymphs and adults is frequent. It occurs because adults are ephemeral and nymphs are sensitive to artificial rearing conditions. As a result, new species, genera and even families of Ephemeroptera are described based only on nymph or adult. Domínguez et al. (2006) reported rearing methods to successfully associate nymph and adult mayfly stages. However, they mentioned that only $10 \%$ of Ephemeroptera species in South America are known in both life stages.

In the genus Baetodes Needham \& Murphy, for instance, most species are known only as nymphs (Nieto, 2004). The genus Prebaetodes was described based only on nymphs (Lugo-Ortiz and McCafferty, 1996). However, the adult stage of this genus was recently illustrated (Chacón et al., 2010). For these genera and many other mayflies, any variation in temperature and oxygenation are critical 
factors in rearing methods complicating the connection between life stages (Domínguez et al., 2006).

Leptohyphes Eaton is another example. This genus has numerous described species based only on one stage of life. In South America, nine species of this genus are known from adults and nymphs, three species are known only from male adults and six were described based only on nymphs (Molineri, 2003; Molineri and Zúñiga, 2006).

A complete knowledge of the life stages of species provides important information for the progress of ecological, phylogenetic and evolutionary studies (Miller et al., 2005; Jeon and Ahn, 2007). There are currently different molecular biology techniques that have used DNA as a taxonomic character in the association of immature and adult stages of insects (Miller et al., 2005, 2007; Fleck et al., 2006; Jeon and Ahn, 2007). For example, Miller et al. (2005) developed strategies for the association of unknown larvae and known adults of Dytiscidae (Coleoptera) using DNA sequence data, with an 806-bp portion of the gene cytochrome oxidase I. In 2007, Jeon and Ahn used the partial cytochrome oxidase II gene $(375 \mathrm{bp})$ to associate unknown larvae and identified adults of the Staphilinidae (Coleoptera). Fleck et al. (2006) used mitochondrial SSU rRNA gene fragments to associate unidentified larvae and described adults of Libellulidae (Odonata: Anisoptera). These works have confirmed that molecular techniques constitute useful tools for the determination of unknown stages of life in species of insects.

In this work, we are proposing the use of "amplified fragment length polymorphism" (AFLP), a molecular technique, to solve taxonomic problems of Ephemeroptera species. The objective was to associate known nymphs and adults of the same species using DNA fingerprints and to generate DNA fingerprints of species that were known only in one stage of life. The species used here were Leptohyphes albipennis Molineri \& Zúñiga, Leptohyphes coconuco Molineri \& Zúñiga, Leptohyphes ecuador Mayo, Baetodes levis Mayo and Prebaetodes sitesi Lugo-Ortiz \& McCafferty. The first two species were used as positive control, since the adults and nymphs were known. They were described in original designation (Molineri and Zúñiga, 2006). The other species were described only as nymphs (Lugo-Ortiz and McCafferty, 1996; Domínguez et al., 2006). Developing molecular fingerprints of nymphs of these latter species would facilitate future associations of unknown adults in future collections.

\section{Materials and methods}

\section{Mayflies studied}

Five species containing 78 specimens were analysed in this research: L. albipennis (ten adults and ten nymphs), L. coconuco (ten adults and three nymphs), L. ecuador (eight nymphs and eight possible adults of this species), $B$. levis (20 nymphs) and $P$. sitesi (nine nymphs). Larvae and adults were collected from two water streams in
Colombia, located in Quebrada Onda, Sandoná, Nariño, 13-18/x/2007, Dias L.G. and Bacca T. cols. Quebrada Genoy Guaico, Genoy, Nariño, S $1^{\circ} 16^{\prime} 24.35^{\prime \prime}-$ W 77²0'16.16", 2.501 msnm. 20-22/IV/2007, Dias L.G. and Bacca T. cols.

The insect samples were deposited in Colección Zoológica, Universidad de Nariño, Nariño, Colombia (PSO). The material containing L. ecuador was deposited at Museo de Entomología, Universidad del Valle, Cali, Colombia (MEUV); Instituto-Fundación Miguel Lillo, Tucumán, Argentina (IFML); and Florida A \& M University, Tallahassee, Florida, USA (FAMU).

Valued body parts of adults and nymphs were mounted on microscope slides in Canada balsam. Drawings were made with a camera lucida attached to an MZ8 Leica microscope.

\section{DNA extraction}

The DNA was extracted from the entire specimen previously preserved in pure ethanol. Total DNA was extracted with the DNA Extraction Tissue Kit (Qiagen) following the manufacturer's instructions. Extracted DNA was stored at $-20^{\circ} \mathrm{C}$.

\section{AFLP technique}

AFLP analysis was performed using the AFLP Analysis System II for small genomes developed by Life Technologies (GIBCO Invitrogen Corporation, Carlsbad, CA) as recommended by the manufacturer. Each sample of genomic DNA ( 125 ng) was completely digested with the restriction endonucleases $M s e I$ and EcoRI. Doublestranded DNA adapters provided in the kit were ligated to the ends of the DNA fragments. Pre-selective primers were complementary to the core of the adapter sequences. The new DNA fragments were then pre-amplified by polymerase chain reaction (PCR) and selective amplification was performed using four primer combinations (AT/CTC, TG/CAA, TG/CAT and TC/CTA) to select the least polymorphic primers for Ephemeroptera. Amplified fragments were separated by gel electrophoresis for $2 \mathrm{~h}$ at $50 \mathrm{~V}$ in 6\% Long Ranger (FMC Bioproducts, Rockland, ME) denaturing polyacrylamide gels. The gels were silver stained and scanned (PowerLook, 2100xl, UMAX) at $300 \mathrm{dpi}$ and greyscale format.

\section{Data analyses}

The presence/absence of each scorable fragment was recorded in a binary data matrix. Data from the two primer combinations selected were combined. A similarity matrix was obtained using UPGMA cluster analysis performed using the software Phylogenetic Analysis Using Parsimony (PAUP 4.0b10 Altivec) (Swofford, 1998). Bootstraping was performed with 1000 replications. 


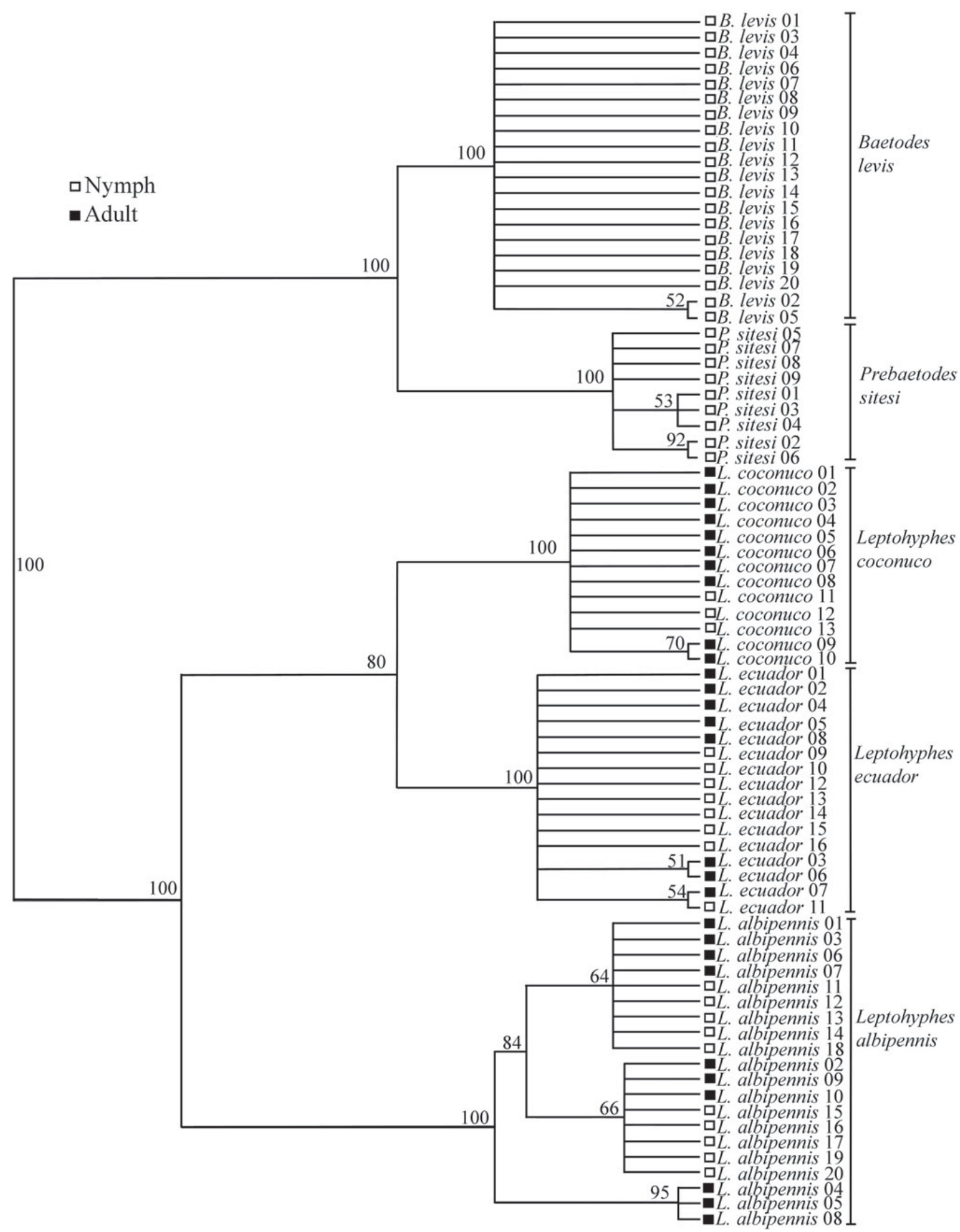

Fig. 1. UPGMA tree based on DNA fingerprints. The number at the right side of the individuals represents the order in the gel.

\section{Results and discussion}

The UPGMA analysis showed that nymph and adult individuals of a single species were grouped together (Fig. 1), and every terminal branch at the species level was supported $100 \%$ by bootstrap analysis, regardless of the location where they were collected. This result was in agreement with the association between larva and adult stages in other insects, when gene sequences were used (Miller et al., 2005, 2007; Fleck et al., 2006; Jeon and Ahn, 2007). 

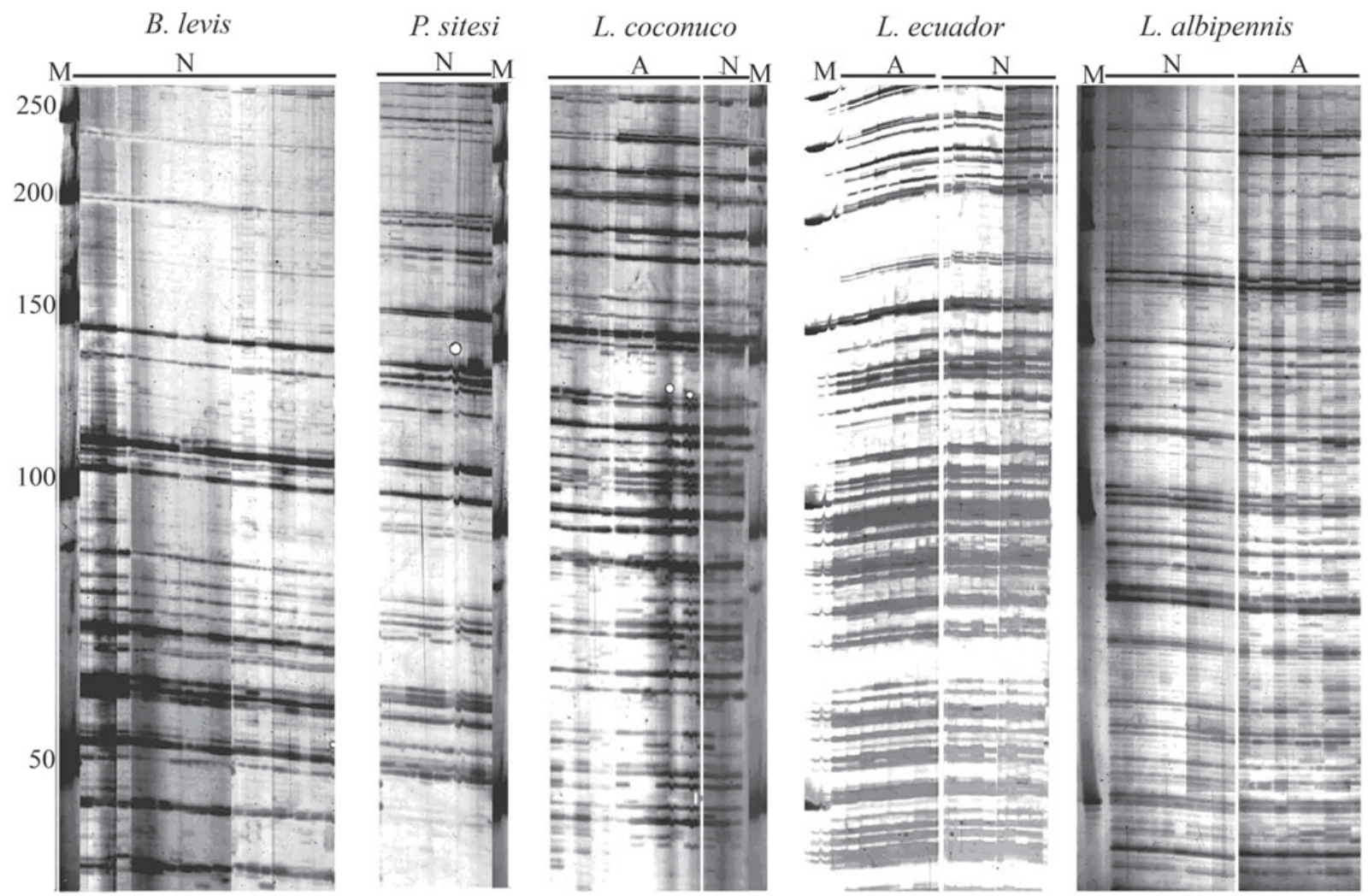

Fig. 2. Gels showing AFLP-based DNA fingerprints of B. levis, P. sitesi, L. coconuco, L. ecuador and L. albipennis using the TG/CAA primer combination ( $\mathrm{N}=$ nymphs, $\mathrm{A}=$ adults, $\mathrm{M}=$ molecular weight marker).

In this research, the AFLP technique revealed advantages in relation to other molecular techniques; for instance, previous knowledge about the gene sequence of the organisms studied was not necessary and allowed exploration and comparison of the whole genome, despite its moderate cost (Fernández-Cuenca, 2004; Meudt and Clarke, 2007). In contrast, the association using sequences required more expensive molecular strategies in order to obtain previous knowledge about the entire extent of variation in the target gene (Miller et al., 2005).

The AFLP technique has been used to establish differences among species or populations based on molecular polymorphisms (Najimi et al., 2002; Zhong et al., 2002; Benavides et al., 2003; Suinaga et al., 2004). Furthermore, we associated nymphs and adults of the same species by getting molecular similarities among individuals. Hence, in order to minimize polymorphism effects in the association, we selected the least polymorphic primers for the analysis (TG-CAA and TG-CTA). Even though we found some polymorphisms in some individuals (Figs. 2 and 3), the branch of all individuals of the same species was well supported (Fig. 3). Besides, a considerable number of individuals were used to guarantee reliability in the associations.

As expected, the adults and nymphs of $L$. coconuco showed similar molecular fingerprints as did L. albipennis (Figs. 2 and 3). These species were described in both life stages (Molineri and Zúñiga, 2006). These results confirmed the efficacy of the AFLP technique in associating nymphs and adults of Ephemeroptera.

We generated for the first time the molecular fingerprints of P. sitesi and B. levis (Figs. 2 and 3). These DNA fingerprints can be used in further research aiming to match an unknown adult found in different regions with the nymphs already described, because the AFLP technique is totally reproducible (Meudt and Clarke, 2007).

In fact, an adult of L. ecuador was associated with its nymph for the first time (Figs. 1-3). This is the first time that L. ecuador has been reported after its description by Mayo (1968) from species collected in Cotopaxi Province in Ecuador. Our findings were made from specimens collected in Colombia at the Department of Nariño.

This association between the nymphs and adults of L. ecuador would have been difficult to determine without using molecular techniques, because the morphology of the adults of this species was very similar to that of the adults of $L$. coconuco. In addition, these species (L. coconuco and $L$. ecuador) together with $L$. albipennis were sympatric, sharing the same hour of adult activity and the same microhabitats as nymphs, as reported by Molineri (2003) and Molineri and Zúñiga (2006) for other species of the Leptohyphes.

In many other orders of aquatic insects, similar association problems occur, for example, Plecoptera and Odonata. In these orders, the species identification is usually based on adults; the nymph does not present sufficient morphological characteristics for identification 

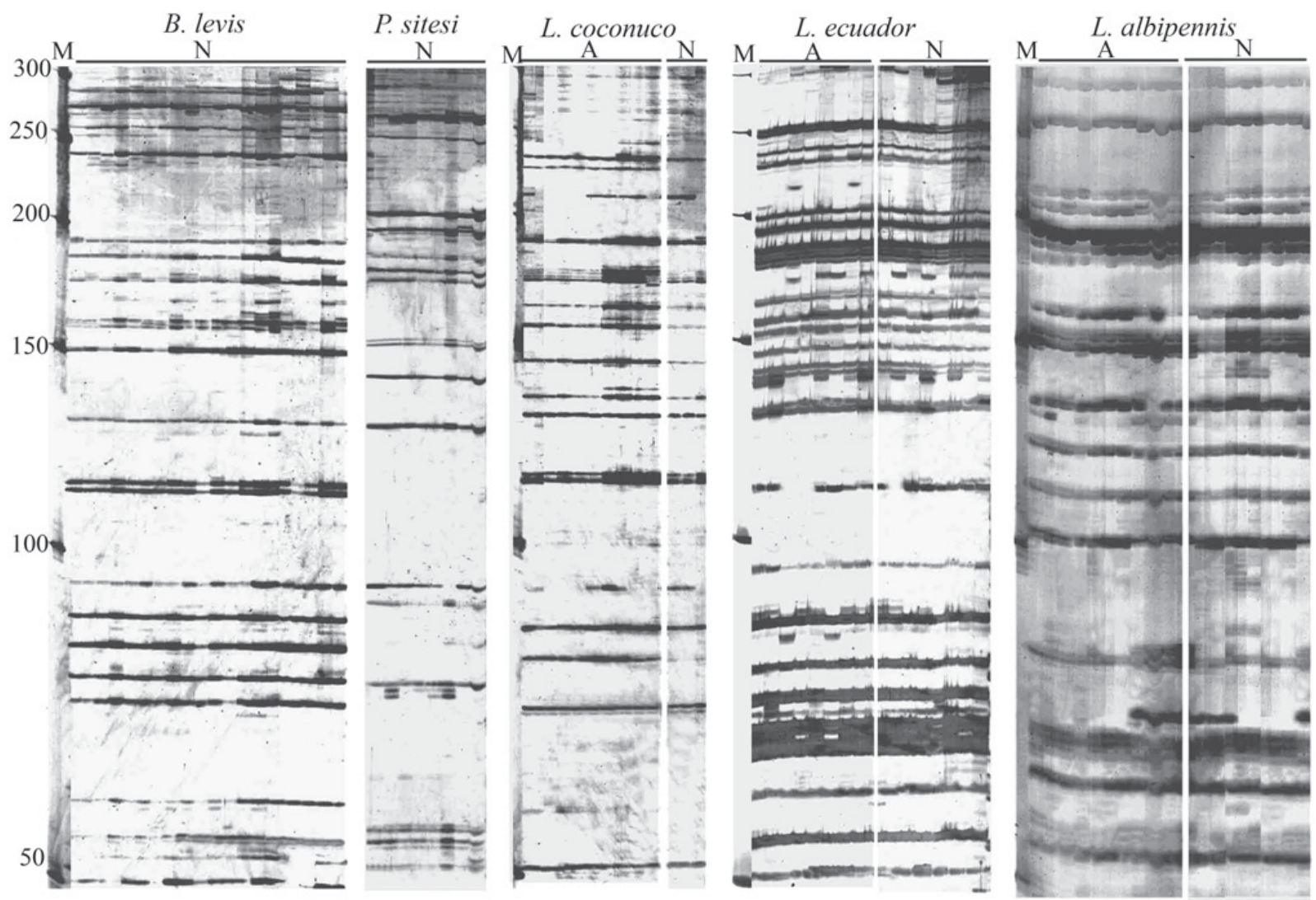

Fig. 3. Gels showing AFLP-based DNA fingerprints of B. levis, P. sitesi, L. coconuco, L. ecuador and L. albipennis using the TC/CTA primer combination.

at the species level, and the identification depends on an established link to unequivocally identified imagines (Fleck et al., 2006; Stark et al., 2009). Given the successful association of these specimens through the AFLP technique, similar success may be expected in associating the adults and nymphs of other insect groups.

In conclusion, the association of nymphal and adult stages of Ephemeroptera through the AFLP technique constituted a useful tool for the taxonomic determination of the group. Besides, this technique is also efficient in the differentiation of closely related species of Leptohyphes genus.

A description of the adults of L. ecuador and additional proposed characteristics to complement the nymphs' description follow.

\section{Description of the adult of L. ecuador Mayo, 1968}

\section{Male imago}

Length: body, 3.2-4.5 mm; forewings, 5.2-6.0 mm; hind wings, $0.6-1.0 \mathrm{~mm}$. General colouration yellowish brown shaded with grey or black.

Head: shaded with black between ocelli, small whitish mark posterior to median ocellus; occiput whitish. Eyes blackish, ocelli whitish rounded with black. Antennae yellowish.

Thorax: pronotum yellowish shaded with grey, except on sublateral region and median longitudinal line; mesoand metanotum yellowish brown shaded with grey; membranous filaments of mesoscutellum completely blackish; mesopleurae, mesosternum and metathorax yellowish, shaded with darker grey on sclerites. Legs yellowish; forefemora, foretibiae and tarsi shaded with grey on dorsal margin; middle and hind femora shaded with greyish black on dorsal marks, on subbasal and subapical regions; tibiae and tarsi yellowish with brownish margins.

Wings (Figs. 4-6): membrane of wings hyaline lightly tinged with yellow, shaded with grey at base and on costal margin; longitudinal veins brownish, cross-veins yellowish. Hind wings with two longitudinal veins (Figs. 5 and 6).

Abdomen: translucent yellowish white shaded with grey, shading darker on pair of submedian longitudinal lines on terga II-VI, and a mediolongitudinal band on terga VII-X darker; abdominal sterna whitish shaded with grey; pleural folds whitish. Genitalia (Fig. 7): penis Y-shaped (Fig. 7); styliger plate whitish with yellowish margins; forceps paler; penis whitish; basal region of the penis slightly expanded, with curved external margin as in Figure 7. Cerci white shaded with light grey; terminal filament whitish-translucent. 

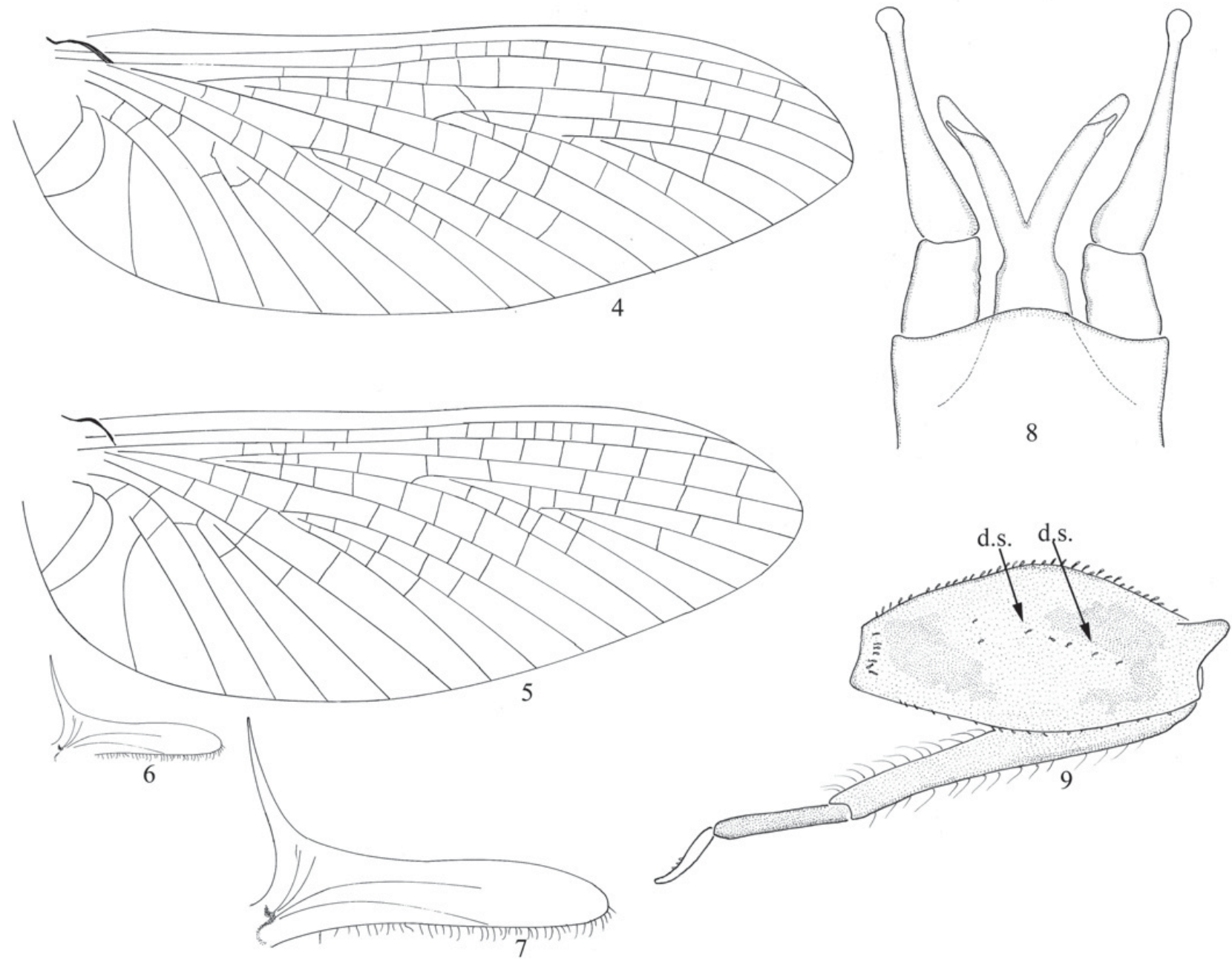

Figs. 4-9. L. ecuador. Adult: (4) male forewing; (5) male hind wing; (6) the same, enlarged; (7) male genitalia, ventral view; (8) female forewing. Nymph: (9) hind leg (d.s. = dorsal spine).

\section{Female imago}

Length: body, 4.0-5.0 mm; forewings, 6.0-7.0 $\mathrm{mm}$. Head and thorax as in male, but darker; membranous filaments of mesoscutellum shaded grey. Wings as in male except usual sexual dimorphism (Fig. 8), hind wings absent. Abdomen as in male. Ninth sternum yellowish brown with anterolateral margins yellowish, apex with a small median notch. Caudal filaments whitish-translucent shaded with light grey. Eggs yellowish with greyish polar cap.

\section{Diagnosis}

L. ecuador can be distinguished from the other species of the genus by the following combination of characteristics. In the imago: (1) occiput whitish; (2) thorax yellowish shaded with grey; (3) veins of wings brownish yellow; (4) hind wings absent in female; (5) membranous filaments of mesoscutellum blackish in male and greyish in female; (6) penis Y-shaped, with basal region slightly expanded (Fig. 7).

\section{Nymph remarks}

An additional characteristic of nymphs of the L. ecuador is mentioned: dorsum of middle and hind femora with mediolongitudinal row of 5-7 spines (Fig. 9).

The presence of this characteristic was confirmed on the holotype of this species deposited in FAMU, and all specimens from Colombia studied in this current work have this characteristic.

\section{Biology and ecology}

The nuptial flight was observed near the stream, 2-3 m above the ground or water. Swarms were numerous and contained hundreds of males; each male moved in the usual up and down manner. The flight was observed before sunrise at 6:00 am and disappeared at 8:30 am. 
Acknowledgements. We thank Vicerectoría de Investigaciones, Universidad de Nariño, Colombia for the financial support. We also thank CNPq for providing funds to LGD to conduct graduate studies at the Universidade Federal de Viçosa. We are indeed grateful to CENICAFE and the Coffee Growers Federation in Colombia who permitted use of their facilities for this project. We also appreciate the help of Dr Jan Peters and Dr Rodolfo Mariano for their confirmation and pictures of some of the characteristics of the holotype of L. ecuador deposited in FAMU and of Dr Terezinha Della Lucia (UFV) and David Long who corrected the English of this manuscript.

\section{References}

Barber-James H.M., Gattolliat J.-L., Sartori M. and Hubbard M.D., 2008. Global diversity of mayflies (Ephemeroptera, Insecta) in freshwater. Hydrobiologia, 595, 339-350.

Benavides P.M., Vega F., Stuart J., Bustillo A.E.P. and Everson J.R., 2003. Biodiversity and biogeography of an important inbred pest of coffee, the coffee berry borer, Hypothenemus hampei (Ferrari) (Coleoptera: Curculionidae: Scolytinae). Ann. Entomol. Soc. Am., 98, 359-366.

Brittain J.E., 1982. Biology of Mayflies. Annu. Rev. Entomol., 27, 119-147.

Chacón M.M., Pescador M.L. and Segnini S., 2010. The adult and redefinition of the genus Prebaetodes Lugo-Ortiz \& McCafferty (Ephemeroptera: Baetidae), with description of a new species fromVenezuela. Aquat. Insects, 32, 143-157.

Domínguez E., Molineri C., Pescador M., Hubbard M.D. and Nieto C., 2006. Aquatic Biodiversity in Latin America, Ephemeroptera of South America, Pensoft, Sofia-Moscow, vol. 2, 646 p.

Fernández-Cuenca F., 2004. Aplicaciones de las técnicas de PCR a la epidemiología molecular de las enfermedades infecciosas. Enferm. Infecc. Microbiol. Clin., 22, 355-360.

Fleck G., Brenk M. and Misof B., 2006. DNA Taxonomy and the identification of immature insect stages: the true larva of Tauriphila argo (Hagen 1869) (Odonata: Anisoptera: Libellulidae). Ann. Soc. Entomol. Fr., 42, 91-98.

Grant P.M., 2001. Mayflies as food. In: Domínguez E. (ed.), Trends in research in Ephemeroptera and Plecoptera, Kluwer Academic/Plenum Publishers, New York, 107-124.

Jeon M.-J. and Ahn K.-J., 2007. Descriptions of late instars of three littoral Cafius species (Coleoptera: Staphylinidae) by association of life stage with DNA sequences. Flor. Entomol., 90, 465-474.

Lugo-Ortiz C.R. and McCafferty W.P., 1996. Phylogeny and classification of the Baetodes complex (Ephemeroptera: Baetidae), with description of a new genus. J. N. Am. Benthol. Soc., 15, 367-380.
Mayo V.K., 1968. Some new mayflies of the subfamily Leptohyphinae (Ephemeroptera: Tricorythidae). PanPacific Entomologist, 44, 301-308.

Menetrey N., Oertli B., Sartori M., Wagner A. and Lachavanne J.B., 2008. Eutrophication: are mayflies (Ephemeroptera) good bioindicators for ponds? Hydrobiologia, 597, 125-135.

Merritt R.W. and Cummins K.W., 1996. An introduction to Aquatic Insects of North America, third edn., Kendall/Hunt Publishing Company, Dubuque, 862 p.

Meudt H.M. and Clarke A.C., 2007. Almost Forgotten or Latest Practice? AFLP applications, analyses and advances. Trends Plant Sci., 12, 106-117.

Miller K.B., Alarie Y., Wolfe G.W. and Whiting M.F., 2005. Association of insect life stages using DNA sequences: the larvae of Philodytes umbrinus (Motschulsky) (Coleoptera: Dytiscidae). Syst. Entomol., 30, 499-509.

Miller K.B., Alarie Y. and Whiting M.F., 2007. Description of the larva of Notaticus fasciatus (Coleoptera: Dytiscidae) associated with adults using DNA sequence data. Ann. Entomol. Soc. Am., 100, 787-797.

Molineri C., 2003. Revision of the South American species of Leptohyphes (Ephemeroptera: Leptohyphidae) with a key for the nymphs. Stud. Neotrop. Fauna Environ., 38, 47-70.

Molineri C. and Zúñiga M.C., 2006. New species of Leptohyphidae (Insecta: Ephemeroptera) from Colombia with evidence of reproductive time segregation. Stud. Neotrop. Fauna Environ., 41, 139-151.

Najimi B., Boukhatem N., El Jaafari S., Jlibène M., Paul R. and Jacquemin J.-M., 2002. Amplified fragment length polymorphism (AFLP) analysis of markers associated with $\mathrm{H} 5$ and H22 Hessian fly resistance genes in bread wheat. Biotechnol. Agron. Soc. Environ., 6, 79-85.

Nieto C., 2004. The genus Baetodes (Ephemeroptera: Baetidae) in South America with the description of new species from Argentina, Bolivia and Peru. Stud. Neotrop. Fauna Environ., 39, 63-79.

Resh V.H. and Jackson J.K., 1993. Rapid assessment approaches to biomonitoring using benthic macroinvertebrates. In: Rosenberg D.M. and Resh V.H. (eds.), Freshwater biomonitoring and benthic macroinvertebrates, Chapman and Hall, V. H., New York, 159-194.

Stark B., Froehlich C. and Zuñiga M.C., 2009. South American Stoneflies (Plecoptera), Aquatic Biodiversity in Latin America, Pensoft, Sofia, Vol. 5, 154 p.

Suinaga F.A., Casali V.W.D., Picanço M. and Foster J., 2004. Genetic divergence among tomato leafminer populations based on AFLP analysis. Pesq. Agropec. Bras., 39, 645-651.

Swofford D.L., 1998. Phylogenetic analysis using parsimony computer program, version 4, D. L. Swofford, Sunderland, MA.

Zhong M., McCarty J.C., Jenkins J.N. and Saha S., 2002. Assessment of day-neutral backcross populations of cotton using AFLP markers. J. Cotton Sci., 6, 97-103. 